\title{
AKTIVITAS ANTIFUNGI GETAH JARAK CINA (Jatropha multifida L.) PADA PERTUMBUHAN Malassezia globosa PENYEBAB KETOMBE
}

\author{
Dyan Ayu Lestari*, Wisnu Cahyo Prabowo, Muhammad Amir Masruhim \\ Laboratorium Riset dan Pengembangan "FARMAKA TROPIS", Fakultas Farmasi, \\ Universitas Mulawarman, Samarinda, Kalimantan Timur \\ *Email: dyanayulestari18@gmail.com
}

\begin{abstract}
ABSTRAK
Indonesia memiliki bermacam-macam tanaman obat tradisional untuk mengobati ketombe, diantaranya menggunakan getah jarak cina. Getah Jarak Cina (Jatropha multifida Linn.) diketahui memiliki beberapa metabolit sekunder yang beraktivitas sebagai antifungi. Metabolit sekunder tersebut fenol, saponin, alkaloid dan polisakarida. Penelitian ini bertujuan untuk menguji aktivitas antifungi getah jarak cina variasi konsentrasi 10\%-100\% dan membandingkan dengan kontrol positif zinc pyrithione $1 \%$. Aktivitas antifungi diuji pada Malassezia globosa dengan menggunakan metode disc diffusion Kirby-Bauer berupa Konsentrasi Hambat Minimum (KHM) dan Konsentrasi Bunuh Minimum (KBM). Hasil uji menunjukkan bahwa getah jarak cina mampu menghambat pertumbuhan Malassezia globosa penyebab ketombe. Data dianalisis dengan analisis varians (ANAVA) satu arah dan dilanjutkan dengan uji LSD (Least Significance Difference). Hasil analisis menunjukkan konsentrasi uji dan kontrol memiliki aktivitas antifungi. Getah jarak cina memiliki potensi aktivitas yang rendah dibandingkan dengan zinc pyrithione 1\%. Getah jarak cina diketahui masih berpotensi menjadi sumber zat antifungi baru terhadap pertumbuhan Malassezia globosa penyebab ketombe.
\end{abstract}

Kata Kunci : Antifungi, getah, Jatropha multifida Linn., Malassezia globosa dan ketombe.

\begin{abstract}
Indonesia has a variety of traditional medicine plants to treat dandruff, such as by using the jarak cina latex. Jarak Cina (Jatropha multifida Linn.) latex have been some secondary metabolites more activity as antifungal. Secondary metabolites mentioned phenol, saponin, alkaloid and polysaccharides. The purpose of this research is to examine the antifungal's activity Jarak Cina latex, variation of the concentration 10\%-100\%, and to compare with positive control $1 \%$ zinc pyrithione. The Antifungal activity was tested on Malassezia globosa by disc diffusion method of Kirby-Bauer, such as the Minimum Inhibitory Concentration (MIC) and Minimum Bacterisidal Concentration (MBC). The result of the test showed that the Jarak Cina (Jatropha multifida Linn.) latex is able to inhibit the growth of Malassezia globosa as the cause of dandruff. The data was analyzed with One Way ANAVA, followed by LSD (Least Significance Different) test. The result of analyzed concentration test and control have antifungal activity. Jarak Cina (Jatropha multifida Linn.) latex have low potential activity compared with $1 \%$ zinc pyrithione. Jarak cina latex still has potential to be the source of new antifungi toward the growth of Malassezia globosa as the cause of dandruff.
\end{abstract}

Key words: Antifungal, Latex, Jatropha multifida Linn., Malassezia globosa and dandruff. 


\section{PENDAHULUAN}

Sekitar $50 \%$ populasi di dunia menderita ketombe dalam berbagai derajat yang berbeda $^{[7]}$. Penderita ketombe diperkirakan $40-50 \%$ dinegara tropis termasuk indonesia terinfeksi Pityrosporum ${ }^{[6]}$. Menurut hasil penelitian Thomas (2007) bahwa jamur yang berperan pada ketombe adalah Malassezia globosa dan Malassezia restricta. Meskipun lebih dikenal dengan genus Pityrosporum. Pityrosporum melepaskan racun kimia, yang menyebabkan peningkatan infeksi jamur ${ }^{[5]}$. Jarak Cina (J.multifida) merupakan bahan alam yang telah di uji memiliki aktivitas antimikroba diantaranya sebagai antifungi. Metabolit sekunder jarak cina yang memiliki aktivitas antifungi seperti senyawa polisakarida, alkaloid, saponin, tanin, dan fenol ${ }^{[2]}$.

\section{METODE PENELITIAN}

\section{Bahan}

Bahan yang akan digunakan dalam penelitian ini adalah getah jarak cina (J.multifida) yang diperoleh dari kebun di samarinda, media jamur yang digunakan SDA (Sabouraund Dextrose Agar) $\quad\left(\right.$ Merck $^{\circledR}$ ) dan biakan murni jamur Malassezia globosa diperoleh dari Laboratorium Biologi Farmasi Unmul, spoid, alkohol 70\%, alumunium foil, kapas, zinc pyrithione, paper disc dan aquades.

\section{Peralatan}

Alat yang digunakan dalam penelitian ini adalah alat kaca, Erlenmeyer (Pyrex ${ }^{\circledR}$ ), Timbangan Analitik (Precisa ${ }^{\circledR}$ ), Inkubator $\left(\right.$ Frailabo $^{\circledR}$ ), Autoklaf (Tomy SN-700 ${ }^{\circledR}$ ), LAF (Laminar Air Flow) (Nuarire-126-400E ${ }^{\circledR}$ ) dan Mikrometer Sekrup (Insize ${ }^{\circledR}$ )

\section{Prosedur}

\section{Persiapan Penelitian \\ Persiapan Sampel Uji}

Penyiapan getah uji dilakukan dengan cara menyayat dengan silet pada tangkai dan batang yang muda. Getah yang keluar ditampung di wadah sampel.

\section{Pembuatan Konsentrasi Getah Jarak Cina}

Konsentrasi yang digunakan adalah 10\%, 20\%, 30\%, 40\%, 50\%, 60\%, 70\%, 80\%, 90\%, dan $100 \%$ dalam $5 \mathrm{~mL}$ aquades.

\section{Persiapan Medium SDA}

Media pertumbuhan mikroba SDA 16,25 gram $/ 250 \mathrm{~mL}$, disterilkan dengan autoklaf suhu $121^{\circ} \mathrm{C}$ dan tekanan 2 atm selama 15 menit.

\section{Persiapan Suspensi Malassezia globosa}

Konsentrasi suspensi jamur Malassezia globosa disesuaikan dengan standar McFarland 1 (3 x $\left.10^{8} \mathrm{CFU} / \mathrm{mL}\right)$ dengan penambahan Nacl 0,9\%.

\section{Pengujian Antifungi}

\section{Metode disc diffusion Kirby-Bauer}

Pengujian dengan metode difusi agar, menggunakan paper disc ke dalam seri konsentrasi getah jarak cina, digunakan kontrol positif berupa zinc pyrithione $1 \%$. Selanjutnya dimasukkan $0,02 \mathrm{~mL}$ suspensi mikroba uji ke dalam cawan petri dan ditambahkan medium pertumbuhan mikroba (SDA) sebanyak $10 \mathrm{~mL}$ dengan menggunakan metode tuang. Paper disc yang telah mengandung seri konsentrasi jarak cina uji, zinc pyrithione $1 \%$ (kontrol positif) dan air suling (kontrol negatif) ditempelkan di atas medium pertumbuhan yang telah diinokulasi dengan suspensi mikroba uji. Selanjutnya diinkubasi pada suhu dan waktu yang sesuai dengan pertumbuhan jamur uji. Inkubasi dilakukan $3 \mathrm{x}$ 24 jam pada suhu ruang $\left(25^{\circ} \mathrm{C}\right)$. Aktivitas sampel uji diukur diameter zona hambat atau bunuh yang terbentuk menggunakan mikrometer sekrup. 


\section{HASIL DAN PEMBAHASAN}

Aktivitas antifungi getah jarak cina terhadap pertumbuhan jamur Malassezia globosa dengan metode disc diffusion Kirby-Bauer telah di uji secara in vitro. Hasil penelitian tersebut menunjukkan kemampuan aktivitas antifungi yang baik. Suatu bahan alami yang mampu menghambat pertumbuhan jamur menggambarkan adanya penghambatan berupa zona bening. Terlihat pada gambar 1. Zona bening disekitar paper disc membuktikan aktivitas fungisidal (membunuh).

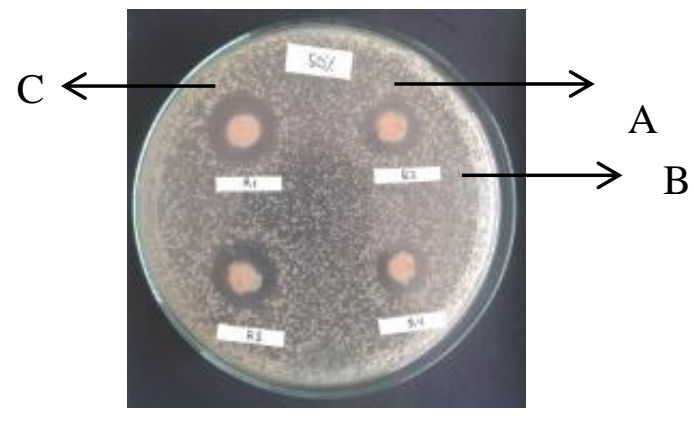

Gambar 1. Hasil Pengujian Getah Jarak Cina (Jatropha multifida Linn.) Terhadap Jamur Malassezia globosa. Konsentrasi 50\% A) paper disc, B) jamur Malassezia globosa, C) zona bening (bunuh).

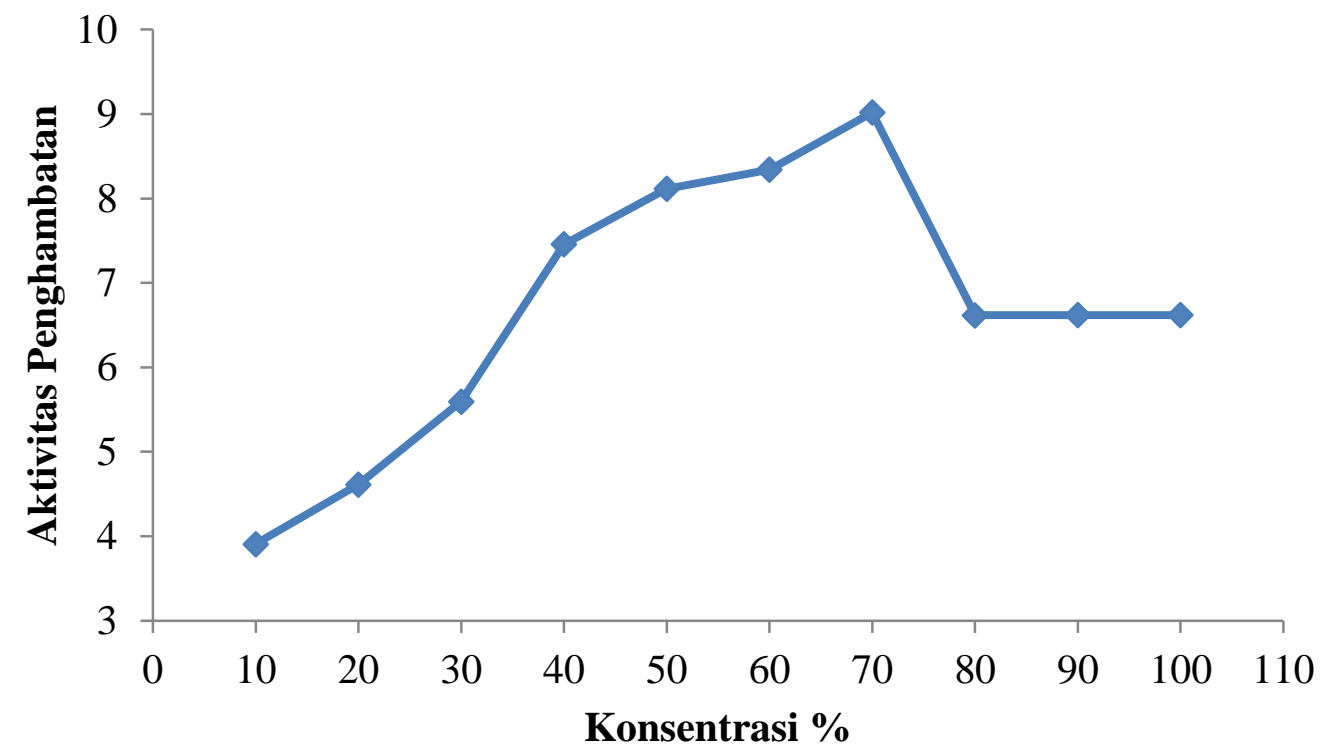

Gambar 2. Grafik Daya bunuh Getah Jarak Cina terhadap Malassezia globosa

Terlihat pada gambar 2. Konsentrasi 10\%-70\% getah jarak cina yang semakin besar menyebabkan diameter zona hambat yang terbentuk di sekeliling kertas cakram juga lebih luas. Menurut Brooks et al. (2005), bahwa efektivitas suatu zat antifungi dipengaruhi oleh konsentrasi zat yang diberikan, semakin tinggi konsentrasi semakin tinggi pula bahan aktif sebagai antifungi sehingga meningkatkan kemampuan daya hambatnya terhadap jamur uji.

Data sampel uji tersebut dianalisis dengan menghitung secara manual One Way ANAVA dilanjutkan uji LSD (Least Significance Difference). Pada analisis One Way ANAVA diperoleh bahwa getah jarak cina memiliki hasil signifikan pada tingkat kepercayaan 95\%. Berdasarkan grafik konsentrasi $70 \%$ merupakan konsentrasi tertinggi dengan aktivitas tertinggi. Hasil pada analisis uji LSD diperoleh konsentrasi $70 \%$ dan $50 \%$ tidak signifikan. Berdasarkan analisis konsentrasi 50\% merupakan konsentrasi bunuh yang efektif. Aktivitas konsentrasi 50\% dibandingkan dengan kontrol positif diperoleh hasil 
analisis Uji LSD sangat signifikan pada tingkat kepercayaan 99\%, dan kosentrasi $50 \%$ belum mampu menyamai aktivitas zinc pyrithione 1\%. Sehingga perlu dilakukan pemurnian untuk mendapatkan senyawa aktif yang lebih efektif.

Hasil penelitian ini menunjukkan potensi antifungi getah jarak cina terhadap pertumbuhan jamur. Menurut Aransiola (2014) getah jarak cina memberikan aktivitas antifungi terhadap Candida sp. pada KBM (Konsentrasi Bunuh Minimum) $525 \mathrm{mg} / \mathrm{ml}$. Potensi antifungi genus yang sama yaitu tanaman jarak pagar memiliki aktivitas antifungi terhadap Candida albicans pada KBM 100\%. Pengujian daun jarak pagar terhadap Malassezia furfur oleh Aniebo (2012) diketahui KHM (Konsentrasi Hambat Minimum) sebesar 29,50 mg/mL. Berdasarkan hasil penelitian ini menunjukkan bahwa getah jarak (Jatropha) terbukti sangat berkhasiat sebagai antifungi.

\section{KESIMPULAN}

1. Getah Jarak Cina (Jatropha multifida Linn.) memiliki aktivitas antifungi terhadap pertumbuhan jamur Malassezia globosa.

2. Konsentrasi 50\% memberikan aktivitas terbaik antifungi terhadap Malassezia globosa.

3. Konsentrasi uji getah jarak cina (Jatropha multifida Linn.) memiliki potensi aktivitas yang lebih rendah dibandingkan zinc pyrithione $1 \%$.

\section{DAFTAR PUSTAKA}

1. Aniebo, C., 2012. Effects Of Jatropha curcas Leaves On Common Dermathophytes and Causative agent Of Pityriasis versicolor In Rivers State, Nigeria. Nature and Science 2012:10(12) Hal. 151-157.

2. Aransiola, Michael Niyi, 2014. Antibacterial and Antifungal Activities of Jatropha multifida (Ogege) Sap against Some Pathogens. IOSR Journal of Pharmacy and Biological Sciences (IOSR-JPBS) e-ISSN: 2278-3008, p-ISSN:2319-7676. Volume 9, Issue 4 Ver. I (Jul -Aug. 2014).

3. Brooks, Geo F., Janet S. Butel, Dan Stephen A. Morse., 2005. Mikrobiologi Kedokteran:Geo F. Brooks, Janet S. Butel, dan Stephen A. Morse, Edisi Pertama, Jilid 2. Jakarta: Salemba Medika.

4. Fathan, Nondy, 2014. Pengaruh Konsentrasi Getah Batang Jarak Pagar (Jatropha curcas L.) Terhadap Pertumbuhan Candida albicans Secara In Vitro. Naskah Publikasi Fakultas Kedokteran Gigi Universitas Muhammadyah Surakarta.

5. Oktaviana, Rifka, 2012. Uji Banding Efektivitas Ekstrak Buah Pare Belut (Itrichosanthes anguina Linn) dengan Zinc Pyruthione 1\% terhadap Pertumbuhan Pityrosporum ovale pada Penderita Berketombe. Skripsi Penelitian Universitas Diponegoro: Semarang.

6. Partologi, Donna, 2008. Pityriasis Versikolor dan Diagnosis Bandingnya (Ruamruam Bercak Putih pada Kulit). Skripsi Penelitian Universitas Sumatra Utara: Medan.

7. Sartika, Dewi, 2008. Perbandingan Efektivitas Air Perasan Bawang Merah (Allium ascalonicum L.) $100 \%$ dengan Ketokonazol 2\% secara In Vitro terhadap Pertumbuhan Pityrosporum ovale pada Ketombe. Artikel Karya Tulis Ilmiah Universitas Diponegoro: Semarang.

8. Thomas, 2007. Malassezia Globosa And Restricta: Breakthrough Understanding Of The Etiology And Treatment Of Dandruff And Seborrheic Dermatitis Through Whole-Genome Analysis. Journal of Investigative Dermatology Symposium Proceedings (2007) 12, 15-19. 